\title{
JUDICIAL REVIEW IN ITALIAN ADMINISTRATIVE LAW
}

\author{
GIUSEPPINo Treves*
}

I

TALY HAS a highly developed system of administrative law. This law applies only to the executive branches of government, including both national and local agencies and incorporated public bodies. Administrative law governs the relations to the public, the organization, and the mutual relations of those authorities. Administrators may, however, make use of private law, that is, the law designed mainly for private persons. Administrative and private law have become more and more interwoven. Matters before left to the individual are now settled by the executive; on the other hand, the executive engages in business enterprises and feels the attraction of the regulation traditionally applied to those enterprises.

When administrative authorities, acting under private law, become involved in a dispute, they are subjected for the most part to the same procedural law which is applicable to individuals. But when they act according to public law or-what often amounts to the same thing-as public authorities, wholly different questions arise regarding the procedure to be followed in the litigation.

The administrative act is the typical expression of the administration acting as such, according to its own law. Administrative acts are bolstered by a presumption of legality that makes them effective and self-executing. Except in well-defined instances, for example cases where personal freedom is involved, an agency does not have to rely on the judiciary to enforce its decisions. It is up to the people adversely affected by the agency's action to challenge the conformity of that action to the law.

Administrative procedural law contains only statutory remedies of universal application; these remedies have been embodied in the 1947 Constitution. There is no need for enabling statutes to provide for judicial review. Jurisdiction is divided between ordinary courts and an administrative court, the Council of State. There are, in addition, some administrative tribunals with limited jurisdiction. The Italian system is, therefore, one of dual jurisdiction, in which the participation of the judiciary is crowned by its power to adjudicate the conflicts of jurisdiction between itself and administrative courts. The jurisdiction and powers of both ordinary and administrative courts are united under the single name of "administrative justice," which includes judicial control as well as adjudication by special tribunals.

Nearly a century of judicial interpretation has built a logical and closely

* Professor of Law, University of Trieste. 
knit system out of a few general legislative provisions. This has been, to a large extent, a creative effort. Judges are not legally bound to follow judicial precedents. But when a principle has been affirmed, it carries a de facto authority that has had a stabilizing influence upon Italian administration. The Council of State is particularly willing to state that an issue has already been examined and decided, that its own teaching is correct, that a principle is well-settled, that there are no grounds for change. But to keep abreast with new needs the Council occasionally makes departures from prior doctrines. Every day fresh problems arise requiring reconsideration of solutions previously adopted. The balance between authority and individual liberty is always shifting.

Historical developments.-An outline of the nature and scope of judical review of administrative action in Italy would be meaningless without some reference to its historical development. Each successive enactment on the subject has made an addition designed to afford better protection to individual rights and interests; no enactment, however, has wrought sweeping changes.

During the first half of the last century Italy was divided into small states ruled by absolute princes. In those states private law disputes between administrative authorities and the citizens, such as questions affecting property, were submitted to ordinary courts. Administrative law disputes proper were reserved to the administrative authorities themselves and to the prince, who would settle them without any guarantee of justice. Some states adopted the French system of administrative tribunals. In 1842 in Piedmont, judicial powers were conferred on local administrative boards and, on appeal, on the Court of Accounts, the central auditing agency. Their jurisdiction extended to the matters expressly stated, such as taxation, public contracts, waters and roads, and fines connected with those matters. The judicial character of the decisions of these boards, which were immediately self-executing without any intervention of the prince, marked an improvement over the French practice of the time.

The events in Piedmont, which in 1848 was granted a constitution, are of special significance because its system of government became the kernel of the government of the united Italy. The liberal ideas prevailing in the parliament of Piedmont condemned the exercise of judicial functions by the executive. Because of their independence the ordinary courts were considered to provide the best protection of the citizens against the executive. A single jurisdiction, such as was adopted in Belgium in 1831, was also more in keeping with the principles of separation than was the French example. Each function would be allocated exclusively to one power. The independence of the executive could be safeguarded by limiting appropriately the powers of the judiciary.

These proposals were embodied in the fifth part of a comprehensive statute enacted in 1865, unifying the administration in Piedmont and that of the states which had in the meantime become annexed to it. That part is still in force today. On the one hand, it suppressed, with a few special exceptions, admini- 
strative tribunals. On the other hand, all litigation between the individual and administrative authorities was entrusted to the ordinary courts. The jurisdiction of these courts included questions of both private and public law, whether or not they were previously heard by administrative tribunals. The object of these disputes had to be a "civil or political right," or in other words, a legal right, private or public, and not some individual interest not enjoying the same status; this distinction will be discussed in the next paragraph. The remaining "affairs," namely questions of interest and the use of discretionary powers of the administration, were left to be settled by the latter.

If the protection of legal rights by ordinary courts is still maintained, the abandonment of these other interests to the discretion of administrative authorities was soon criticized. The decision of administrative remedies was uncertain and uncontrolled. The rule of law, it was claimed, required a judicial defense of these interests as well. Such a defense was once secured by the administrative tribunals whose jurisdiction was not limited to controversies over legal rights. There was no question of repealing the Act of 1865. The discussion was focused on its completion and improvement. The judiciary was held to be unfit to adjudicate those individual interests so closely connected with the public interest. But an independent administrative agency of the French type could well be vested with judicial powers.

The reform was brought about in 1889. A new section, the fourth, was added to the Council of State, the highest advisory body of the country. The new section was endowed with power to adjudicate all questions relating to those interests which pertained to the individual as such, and not as a member of the community; these were the interests termed "legitimate." In special cases the Council was empowered to examine, besides issues of legality, the use of administrative discretion. Provincial boards were given jurisdiction over some classes of local disputes; there was provided a right of appeal to the Council from the decisions of the boards.

In 1877, conflicts arising over the jurisdiction of ordinary and administrative courts were consigned to the joint sections of the supreme judicial authority, the Court of Cassation.

The distinction between the two jurisdictions still remains of paramount importance, only minor alterations having been made since the original division. Thus, owing to the increased amount of work, another judicial section of the Council of State, the fifth section, was set up in 1907, and a sixth was created in 1948. The rules of procedure also date from 1907. Since 1923 the judicial sections have dealt with both legality and discretion cases. Owing to the difficulties encountered in distinguishing legal rights from legitimate interests in some matters, the reform of 1923 extended the Council's jurisdiction to all questions of legitimate interests, even though they concerned legal rights.

The Constitution of 1947 reaffirmed the distinction between the jurisdiction 
of ordinary courts and that of the Council of State. ${ }^{1}$ Although in novel and borderline cases the distinction is as hard in practice as it is in theory, no voice was raised for its abolition. The authority of the Council of State stands very high because of the independence and skill it has demonstrated. Nevertheless, this has not reduced the trust placed in ordinary courts, however less specialized they may be in administrative matters and however less felt today is the need for a dichotomy. Only some technical improvements are still urged, especially with regard to the delays caused by the large number of cases-the Council issues well over three thousand decisions each year-and the working of local boards. Of particular significance is the constitutional provision that a judicial protection is "always" granted against the acts of administrative authorities. All restrictions placed upon this constitutional right are thus invalid.

The Constitutional Court that has now been set up to review legislative enactments does not alter the pattern above described. When the executive injures a right of the individual guaranteed by the Constitution, there is no special remedy. The ordinary and administrative courts can provide sufficient relief. Only when, in the course of a judicial controversy, the statute to be applied is alleged to be unconstitutional, will the judge adjourn the proceeding and refer the issue to the Constitutional Court. When dealing with legislation passed before the Constitution, the judge may himself decide whether the latter document repealed the statute.

The distinction between legal rights and legitimate interests.-As already mentioned, this distinction is the kernel of judicial review. The jurisdiction of the two different sets of courts, the ordinary and the administrative, rests on the nature of the interest affected. The problem of standing in administrative litigation is increasingly recognized everywhere as administrative law develops. Public and private interests are often intermingled. The degree of interest necessary for standing to challenge administrative action varies from country to country. A special nuance is added in Italy and has become the element which has given jurisdiction to one court rather than the other. This has tended to crystallize distinctions which are only matters of degree.

The separation of legal rights from other interests equally protected by the law sounded simple to the last century's legislators and still remains sufficiently clear from the point of view of jurisprudence. A legal right is an interest protected by the law, but not every such interest constitutes a right. To be ranked as a right, the interest of a person ought to be protected by the law inasmuch as it belongs to him directly, immediately, as such, and as correlative to an obligation. This is the sort of interest that both parties derive from a contract, that a government officer has for the payment of his salary or of the pension accrued to him, or that a citizen claims against a police attempt to enter the sphere of civil liberties recognized in him by the Constitution. A legitimate or qualified interest of a person is also protected by the law, but the protection

${ }^{1}$ Art. 113. 
received is only occasional, indirect and mediate. It is received only through the satisfaction of a general interest to which it is subordinated. The rules that any agency has the duty to apply, e.g., in a competition to enter government service or in the granting of a license, aim at securing a benefit to the general interest, such as getting the best officers in the service of the nation or preventing an unfit person from damaging the public. Compliance by administrative authorities with the formalities required for these proceedings will secure the protection of individual applicants as well. The individuals have, however, something less than a right to it. The law may impose limitations on some industrial activities on health or police grounds, or subordinate the licensing of new buildings to a town planning scheme; that is, the law may impose restrictions for the benefit of the public. This implies that individuals may obtain a concrete good from observance of the law, but their benefit is merely a by-product of that accorded to the general welfare. ${ }^{2}$. The following examples may be used. The only chemist in town has a legitimate interest that another license should not be granted unless the prescribed procedure is followed. ${ }^{3}$ The firm which applies for a business license which its competitor also seeks likewise has a legitimate interest that the proper procedure be adhered to. However, no such interest is held by the firm which had not applied, or is not invited to tender an application for a government contract. ${ }^{4}$ In these examples the interest of the individual person or firm is too remote to ground a claim for relief. The same is true of the individual interest in the fulfillment of many another duty of the executive, such as that to provide street lighting. The individual interest in such cases is not protected. The protection of the general interest may depend not on the law, but on the exercise of a discretionary power by the executive. This power has to be discharged with a view toward the maximum public good and the minimum individual sacrifice. The citizen has, of course, an interest in the reduction of the rate of a tax or in the construction of a public road near his farm, but he has no judicial means by which it may be enforced. This is what is called a "simple interest."

Administrative lawyers have refined this doctrine from various angles. For instance, a right, such as that of property, may be reduced to an interest when the executive has discretionary power to dispose of it, e.g., by requisition. On the other hand, a person has only an interest in the issuance of a discretionary license; but once he has obtained it, he may acquire a right to it. But the crucial problem lies in the practical application: where should suit be brought? How is one to know whether his own private interest is protected

\footnotetext{
2 Parisi c. Comune di Napoli (Council of State, 5th Sec., Dec. 19, 1958, No. 1102), C.S. (the initials refer to "Consiglio di Stato," one of the unofficial reports of the Council's decisions) 1958, 1480, 1483.

3 Novellino c. Prefetto di Avellino (4th Sec., Apr. 7, 1956, No. 363), C.S. 1956, 385.

1 Soc. Impresa Generale c. Prefetto di Genova (5th Sec., Nov. 22, 1957, No. 999), C.S. 19571444.
} 
directly or indirectly, or, in other words, whether the law intended to protect a private or a public interest? The courts have worked out a criterion that is far from being perfect but may prove to be useful in many cases. If an individual denies the existence of a power, however discretionary, of an administrative authority to affect his legal sphere, the question is one of legal rights to be settled by the judiciary. ${ }^{5}$ The right of property would be violated by a compulsory purchase of land for which power has not been granted. On the other hand, the exercise of an existing discretionary power cannot infringe a legal right any longer, but only an interest, and that exercise will have to be reviewed by an administrative court. Thus an alien has no right to enter, or reside in, the national territory; for the authorites have to consider security interests before permitting the residence. ${ }^{6}$

To take another knotty question, but one now settled, once a private-law contract is concluded between an agency and an individual, the latter may demand performance of the contract. Ordinary courts will have jurisdiction. But the concluding of a contract is preceded and followed by discretionary acts of the agency concerned, such as the decision to enter into the agreement, choice of the other party, or the consent or approval of a higher authority. The disputes relating to these acts will affect only a legitimate interest and will be taken to the Council of State. ${ }^{7}$

The violation of a legal right or legitimate interest, or causa petendi, is the first criterion on which the jurisdiction of the ordinary or administrative court will depend. But, as we shall see later, different relief is granted by the two courts. As a rule, the former may state that an action is illegal and award damages; the latter may annul an illegal act. The complainant's request, the petitum, will then concur with the previous criterion in determining the jurisdiction. Both of them require a joint consideration.

Review by the judiciary. - Usually the intervention of the courts is invoked not by the administrative authorities but by the individual who alleges that his right has suffered from the actions of those authorities. Only when a relationship is governed by private law will the executive be forced to sue for the fulfilment of his claims. It is doubtful how far an authority can forfeit its privilege of self-defense in administrative matters. The plaintiff is then only a private individual or even a public corporation bringing suit against another private individual or government agency. The plaintiff sues the executive for a violation of a legal right; the relief asked for is a decree that the executive action is illegal. This decree is somewhat like a declaratory judgment. In taxation cases the plaintiff has first to pay and then bring his action to recover the

\footnotetext{
${ }^{5}$ Lack of any power for the Court of Cassation: Cimatti c. Ministero industria e commercio (Joint Sec., Feb. 6, 1959, No. 383), 84 F.I. ("Foro italiano," a general law report) 1959 I, 195, 197; when a power is exercised beyond a matter subjected to it for the Council of State: Baldo c. Comune di Chioggia (5th Sec., Oct. 25, 1957, No. 879), C.S. 1957, 1285.

'Schacherl c. Ministero interni (Council of State, Plenary meeting, Sept. 15, 1956, No. 12), :S. 1956, 1113.

7Impresa Picano c. Comune di S. Elia (5th Sec., Dec. 5, 1958, No. 935), C.S. 1958, 1492.
} 
excess collected, solve et repete. As a tribute to the principle of separation of powers, the suit in general does not suspend the execution of an administrative act. Nor, for the same reason, may a judge order or enjoin any action by the executive, nor modify or annul an administrative act found to be illegal. Taking such steps would imply the exercise of an administrative function and would constitute the substitution of the judge's will for that of the executive; this would violate the latter's independence. Here as elsewhere, some exceptions are created by the statutes; exceptional orders are the annulment of a marriage or the order to produce documents. When, however, an agency acts not as a public authority but as iure privato, the judge is entitled to annul its contracts or issue orders to it as if it were an individual.

The repeal of an act held by a court to be illegal will be carried out by the administrative agency which is bound by the decision. An appeal lies to the Council of State against its refusal. Res judicata does not extend beyond the act that was challenged, in relation to the question at issue. The agency is not bound to follow the decision with respect to other persons affected by the same act.

It is universally admitted that the judge can also order the agency to pay a sum of money, which is due because the agency illegally refused to recognize a title or because the agency otherwise caused damage. Such an order does not entail judicial intervention in the management of a public service. No compensation in kind can, however, be ordered by the court, because the separation of powers is held to block it.

The administrative authority is fully liable in contract as well as in tort. Its liability finds an indirect basis in Article 4 of the Act of 1865, as this gives ordinary courts jurisdiction over the "effects" of its illegal acts. As often occurs, substantive aspects of administrative law depend on, or are conditioned by, procedural rules. The Constitution has now explicitly affirmed the liability of all officers and employees of state agencies and public corporations for actions violating legal rights, and this liability, under Article 28, extends to the authorities as well.

The judiciary may also have to consider the legality of an agency's act indirectly and incidentally, rather than as a result of a direct attack on it. This occurs when the agency defends itself claiming that one of its acts is illegal, or when an individual is damaged by an action carried out in the execution of an agency act he claims is illegal. This may also occur in litigation between private parties, as in cases involving the validity of a license. This indirect attack may also occur in criminal cases where there is a dispute over the validity of an order or regulation that has allegedly been violated.

According to Article 5 of the 1865 Act the judge applies an act or regulation only insofar as it is in conformity with the law. Otherwise he should not apply it. The review of an abuse of discretionary power is always excluded because only interests are involved; such matters are left to the Council of State.

Proceedings before ordinary courts are governed by the same principles 
which apply to proceedings between private parties. Special rules apply to the service of writs on government agencies and to the representation of the latter by a body of government lawyers. The ordinary rules of evidence are also held to apply. Some initial difficulties raised by oral examination of an agency and the oath to be taken by it have been overcome. Although doubts were once expressed about the enforcement of judgments against the government, it is now agreed that in this case force would be used on behalf of one power of the state, and the executive could not lawfully resist it. This principle is applied only to the payment of a sum of money, because no other relief can be given by the judiciary. Execution may be levied on real and personal property, but some such property is exempt. No difficulty has arisen as to costs.

Administrative tribunals.-Administrative tribunals are all special, in contrast with ordinary courts, as their jurisdiction is limited. They are "administrative" not so much because they are agencies of the executive as because they have jurisdiction over administrative controversies to which the administration - be it a state agency or a public body-is a party. Administrative agencies adjudicating civil or criminal cases are considered to be special, but not administrative tribunals. The number of administrative tribunals is large. But, by long usage, administrative jurisdiction without further indication is taken to refer to one agency only, endowed with a general jurisdiction over all sorts of administrative matters. This is the Council of State sitting in a judicial capacity. Just as ordinary courts are vested with general jurisdiction over legal rights, so the Council is enabled to adjudicate all legitimate interest cases. In practice the provincial boards are placed on the same footing, although their jurisdiction is not general; for those boards adjudicate, as first instance tribunals, cases reviewable on appeal by the Council. The remaining adjudicative agencies have specialized jurisdictions. The jurisdiction of any particular agency may be fairly broad, however; this is true, for example, of the Court of Accounts which has authority over public servants' pensions and responsibilities of the public waters tribunals, and of the various taxation boards. In very few instances does a minister act in a judicial capacity.

As the Council of State-and the same is true for most administrative tribunals-has jurisdiction over disputes that are withdrawn from ordinary courts, its decisions are not appealable to the latter. When, however, the Council has pronounced judgment in a controversy that is alleged to be within the jurisdiction of ordinary courts or of another administrative court, or to the administration itself, the Court of Cassation will settle the jurisdictional issue. The same is true if the Council has refused to adjudicate a controversy attributed to it. These cases present a "conflict of jurisdiction." Such a conflict may also arise from the decision of an ordinary judge. A case may be taken to the Supreme Court even while judgment is still pending.

The Council of State now contains three advisory and three judicial sections. A quorum of seven members, chairman included, is required for the meetings 
of each section. Every year from two to four of the members of each section are interchanged, to secure a rotation between advisory and judicial personnel as well as a continuation of policy. The three sections in each group have the same powers. Work is distributed among the sections by the President of the Council. The Council sits judicially in plenary sessions with members drawn from all judicial sections, plus the President, when a question of law has given or may give rise to conflicting precedents or the issue involved is of particular importance.

Councillors are all appointed by the President of the ministers' Council. Half of the vacancies are filled by promotion of assistant councillors, selected in a public competition open to all public officers. The remaining half are chosen usually from among high-ranking officers. The status of councillors cannot be altered except by statute. They enjoy a large amount of independence: for they cannot be compelled to retire except when they are physically disabled; they cannot be transferred without their consent, nor suspended or removed except for negligence or refusal to carry out their duties. The whole Council assembled together must recommend disciplinary action.

Less marked is the independence of provincial boards. When sitting judicially each of them is composed of the prefect, who is the government-appointed head of the provincial administration, two of its officers, and two members chosen by the elected provincial council. The boards' jurisdiction is sometimes confined to issues of legality, but as a rule their jurisdiction is extended over the discretion exercised in performing some act and over questions of rights. Thus they generally have jurisdiction very similar to the special jurisdictions of the Council of State. The latter is vested with the same powers when deciding appeals from the judgments of the boards.

It is held that a reform of these provincial bodies is urgent, especially in consideration of Article 125 of the Constitution. That article envisages the institution of administrative tribunals of the first instance which are provided with regional jurisdiction. In the meantime, Sicily-the region with the greatest autonomy-has obtained the establishment in the island of an administrative justice council. This council is presided over by a section chairman of the Council of State and includes two of its councillors and two lawyers locally elected. It acts as a tribunal of the first instance for actions of government authorities in Sicily, as the exclusive tribunal for adjudicating disputes over the actions of regional authorities, and as an appeal tribunal for decisions of Sicilian provincial boards. In the first case, appeal lies to the plenary meeting of the Council of State, to which the Sicilian council may also refer an issue when the precedents are in conflict. In the remaining cases, the decision of the administrative justice council has the same finality as a judgment of the Council of State. Consequently no appeal is allowed except to the Court of Cassation and then only where there allegedly is a "lack of jurisdiction." Another region endowed with a special status, the Aosta Valley, has its own 
board in place of the provincial board. The former board has jurisdiction over actions of regional authorities. Appeals may be had to the Council of State, or the Court of Accounts, for the financial questions entrusted to the board.

Administrative remedies. - The control of the executive over its own acts may be prompted ex officio or by a citizen. In the latter case the citizen's complaint may receive legal recognition and the executive is bound to take it into consideration. We have then an administrative remedy. Its exhaustion is a prerequisite to a judicial appeal to the Council of State. Administrative remedies came first in the development of review of administrative actions and still are practically the only way of seeking redress for an act that is legal, when the exercise of the discretion committed to an agency is criticized. Though permissible, administrative remedies are not requested before bringing an action in an ordinary court for the violation of a right, as some other relief besides repeal of an act may be sought.

There are three stages or classes of administrative remedies. The first is an appeal to the same authority that has issued the act challenged. It is legally recognized in only a few cases. This means that in all other cases the "appeal" will amount to a simple petition or denunciation without any obligation being placed on the agency to heed it.

The second and more generally available remedy is the hierarchical appeal, that is, the appeal to a higher administrative authority-usually the ministerfrom the act of a subordinate authority. Only one appeal is allowed, even if there are more than two echelons: an exception is made in cases involving military administration. The appeal does not suspend the administrative act, but a stay may be granted. The remedy is available with respect to both questions of legal rights and interests, of legality and discretion, and of law and fact. The appeal may also be necessary, since the complainant may not appeal to the Council of State before exhausting heirarchical remedies. The rule requiring exhaustion of administrative remedies is prompted by the desire to give the executive a chance to resolve a contested case. The wish to reduce litigation also plays a part. The decision of the appeal, as well as the act that was originally issued by the head of a department or by an independent public corporation (or even, in some circumstances, by a local agency such as the prefect), are "final" and may be attacked before the Council of State. From acts of local authorities an aggrieved party has the choice between a judicial appeal to the provincial board and an administrative appeal to the same board with a slightly different membership.

The third appeal is a relic of the past, when the prince was administering justice as of grace as the only means of restraining arbitrary action of the authorities. This appeal is addressed to the head of the state and can be taken only on grounds of legality. It is parallel and alternative to the appeal to the Council of State. A "final" act is therefore a prerequisite. The prior exhaustion of the ordinary hierarchical appeal is likely to have caused the qualifi- 
cation of "extraordinary" to attach to this remedy. The minister who issued the act attacked will consider the case and then ask the advice of the Council of State, jointly assembled in all its sections. The decision lies with the minister, who will present it to the President of the Republic for his signature. The presentation is a mere formality since the President cannot refuse to sign. If the minister does not agree with the advice received, he will have to submit the issue to the Council of ministers. There is no appeal to the Council of State from the decision except for defects of form. This is because the Council of State has already expressed its opinion. This is an application of the rule ne bis in idem. Despite the limited opportunity provided for the defense, this remedy has some advantages. It involves a small expenditure, and the time allowed to perfect the appeal-180 days from the notification or knowledge of the administrative act-is greater than that set for a judicial appeal to the Council of State-sixty days. The former is still possible when the judicial remedy is barred. The period available to bring a suit before ordinary courts for the infringement of an individual legal right is considerably longer.

As already mentioned, administrative remedies are not exclusive of judicial ones; on the contrary, the former may be a condition precedent to the latter. When an individual wrongly applies to the executive, instead of appealing to the Council, he may forfeit his right of appeal to the latter because the period of limitation may have expired. This period, however, may be suspended if the appeal was not taken because of a reasonable mistake. On the same grounds a short delay may be granted by the Council for the exhaustion of the administrative remedy if the administrative act is not yet "final."

These remedies constitute what is called the "administrative protection" of the rights and interests of the citizens. A decision must be classified as either administrative or judicial, since different remedies are given in the two cases. Here the authority determining the appeal, the procedure, and the form of the decision are administrative. The inner nature presents mixed administrative and judicial features, but the former are deemed to have the upper hand. The executive is simply exercising its power of control over its own illegal acts on the public interest, even when deciding a dispute. Individual interests are protected only indirectly. The judicial element becomes an instrument for the pursuit of administrative ends.

The agency has a duty to decide the appeal, and the appellant a right to obtain a decision. Should the agency fail to pronounce its judgment within four months from the appeal, the aggrieved party may request that a decision be issued within the next two months. If this period expires without a decision issuing from the agency, the "silence" is tantamount to a negative decision. This is construed as a "final" act, enabling the individual to appeal to the Council of State to set it aside.

Only administrative acts are appealable. Before action is taken the individual may seek relief in a petition or application that the agency has no obligation 
to answer. This appeal has to be taken to the agency that issued the act. All parties concerned may submit documents and briefs and invite the agency to make further inquiries. The agency is, in any case, free to carry out inquiries or ask for the advice of any competent authority. Rejection of the appeal implies confirmation of the administrative act. That act may, however, be annulled later ex officio, though on different grounds. As no question of res judicata is involved, circumstances of public policy may also call for the repeal or replacement of the administrative act. If the appeal is held to be well-founded, the agency annuls the act attacked; the annullment takes effect retroactively. A new act may be issued, provided of course that it is not subject to the defects inherent in the prior act and recognized by the decision on appeal. If the appeal is rejected, the appellant may apply to the Council of State; similarly, the other interested parties may take their case to the Council if the act is annulled.

Some further principles governing judicial appeals may be extended by analogy to administrative remedies.

The general jurisdiction of the Council of State.-The Council of State has three kinds of jurisdiction. One is general and extends over the legality of acts violating legitimate interests. Two kinds are special, that is, one is over issues of discretion as well as legality and one is over issues of rights as well as interests The first is general insofar as it is available in all matters, whereas the other two have to be expressly authorized by law.

The general jurisdiction of the Council over legitimate interests is parallel to that of ordinary courts over legal rights and is similar to the annullment jurisdiction of the French Conseil d'Etat. The appeal is granted only on grounds of legality, as with appeals from a lower to a higher court, but the Council examines into questions both of law and fact. The appeal is directed against an administrative act understood in a formal manner, more restricted and technical than the administrative action reviewable by ordinary courts. The administrative act is an act by an administrative authority that is not considered to be the exercise of a legislative function-as some instances of delegated legislation-or of a judicial function-as the decisions of the Council itself and of the other administrative tribunals. Just as the acts of the legislature or the judiciary are not submitted to the Council, even if they may be considered to be substantially executive in nature, so the jurisdiction of the Council does not extend to acts of the executive which have the same substantial nature as a statute or a judicial decision. The sharp distinction that Italian law draws among the acts required for the exercise of the various powers finds its application here. By-laws and administrative regulations, however, are included in the notion of administrative act; for they are issued in the exercise of a predominantly executive power. The same is true of some decisions which might be said to have some quasi-judicial aspects.

It is debatable whether the review of political acts, similar in some respects 
to Acts of State, is still barred as in the past. These acts refer to the supreme leadership of the body politic, such as the summoning or dissolution of Parliament or the appointment of ministers. They may only remotely affect the sphere of individual legitimate interests. Security measures by less than the highest authorities, even if issued on political grounds, do not belong to the same class. At any rate, political acts seem to fall within the constitutional clause granting judicial protection against the acts of the executive in all cases. Since that protection cannot be excluded or limited to particular remedies or for some categories of acts, according to Article 113, the prior limitations should be considered to be repealed.

This does not mean, however, that all executive acts may be attacked. Some acts are not such as to injure individual interests. They may have an effect within the administration only. Examples are circulars or service instructions. The same is true for other acts, such as findings, announcements, or advisory opinions, which are not likely to infringe directly private interests. A birth or similar certificate may be wrong and should be rectified, but there seems to be no reason to allow an appeal in such cases. If an act is simply the confirmation of a precedent involving a similar measure and is the result of the insistence or the disobedience of the interested party, there is no appeal to the Council when the period of limitation for the appeal against the prior act has already expired. Similarly the execution of an act is merely the materialization of its effects, unless that act had not been made known beforehand. Acts which are part of a proceeding are not reviewable alone, but only jointly with the final act which will affect individual interests. Previous defects are reflected in this act and invalidate it. Thus, irregularities arising in the course of a public service competition will injure the candidates when the winners are selected. But the act prescribing the conditions for the appointment may immediately injure the candidate who has already attained the age limit unlawfully set. Moreover, since appeal is allowed for the purpose of having an act quashed and no other type of relief is possible, the existence of an act to be quashed is obviously necessary. A mere tortious action does not qualify. But the behavior of the agency such as a failure to act when it has a duty to do so may be taken as a refusal, as in the case of an administrative remedy left without answer, and be appealable. These principles, which are the result of long and constructive work by the Council of State, imply that the Council can adjudicate only the legality of an administrative act. This act is the product of the exercise of a power, but the exercise itself cannot be reviewed except through review of the act itself.

It has already been pointed out more than once that an administrative act may be challenged before the Council of State only when it infringes an individual legitimate interest. To receive protection this interest must be actual; that is, no appeal is granted for an injury that has not yet occurred even though it is threatened. No regulation can be attacked until a person is injured by its 
application or enforcement. On the other hand, the interest must be direct or personal, namely the interest of the individual as such, and not as a member of the community. The interest in good administration, in the smooth working of a public service or in equal taxation, is entrusted to the public authorities concerned. The citizen has only a "simple" interest in this. Only in exceptional cases, such as where local taxation is involved, has he a right to sue as a representative of the public interest, not uti singulus but uti civis, with a so-called "popular action."

Persons indirectly affected by an act may intervene, but not if they had sufficient standing to obtain review. Otherwise they would frustrate the short time limit set for the appeal.

The Council may also have to decide preliminary or incidental questions pertaining to legal rights, such as the status of a party or the nature and property of a thing, but such a decision does not acquire binding force as respects other disputes.

The scope of the Council's review is fairly easy to determine. It will set aside any administrative act that is unlawful. And before deciding whether the law has been correctly applied or not, it is entitled-like any other judge-to establish the facts. Doctrines such as those of fact, law; and mixed questions, substantial evidence, jurisdictional facts, error on the face of the record, quasi-judicial and ministerial acts, and the like, lose their meaning when review is so broad as to include any irregularity. The appeal to the Council is a sort of general certiorari applicable to all administrative acts. No other judicial remedy is available. The Council is not empowered to modify an act or to order the executive to do something or to enjoin the executive from doing it. The Council will either reject the appeal or quash the illegal act, wholly or in part, though it may grant temporary relief from execution of the act while review is pending.

The vices of administrative acts that make them ultra vires have been grouped by the law under three headings - "lack of jurisdiction," "excess of power" and "violation of the law." These headings are meant to include all illegalities and have to be understood in a conventional sense. The first type of irregularity occurs when an act comes from a public agency or body other than that having jurisdiction to issue it. The authority may be higher or lower, or entrusted with another territory or another matter. "Violation of the law" refers to defects such as non-observance of rules concerning the proceeding and its formalities, or to an illegal content. "Excess of power" is more subtle and needs more explanation. Originally it corresponded to one aspect alone of the French "excess," namely the dêtournement de pouvoir. The "excess of power" concept was taken to imply the use of an administrative power for a purpose different from the one intended by the law when it conferred that power on a public authority. This is still the view held by some writers. But in view of the difficulties encountered in proving that an act has pursued a wrong end, reliance has been placed on some symptoms which may reveal the exceeding 
of power. These symptoms tend to become independent figures of excess. Everything which may affect the will of administration is classified under the all-embracing concept of "excess of power." This is true even if the legislative purpose happens to be realized. Violation of due process, abuse of power, capricious or arbitrary use of discretion, error of law and fact, bad faith, corrupt, collateral or irrelevant motives, unreasonableness, infraction of the rule of natural justice, may all easily be included. Discretionary power not being subject to review, the judge has to confine himself to probing its contours. Often he will analyze the whole behavior of the administration, to make sure that it was not prompted by motives or purposes other than those for the fulfilment of which a discretionary power was granted.

Some recent, typical examples will clarify the extent to which the Council of State has carried its power to review. The refusal of a mayor to approve a house as fit for habitation is illegal when it is based on town planning rather than health considerations. ${ }^{8}$ If an urgency order is based on findings made some years before, the sacrifice of a private interest cannot be held to be useful for the attainment of the public purpose aimed at by the law. ${ }^{9}$ When a license is granted as the result of mistake, ${ }^{10}$ or an estate is subjected to limitations because wrong assumptions are made, ${ }^{11}$ the errors will affect the agency's judgment on the public interest. The existence of a conditioning element may also be appraised by the court even if it is discretionary..$^{12}$ The court may also appraise the criteria governing the decision of a public competition if those criteria are illegal or illogical. ${ }^{13}$ Officers on the same plane have to be treated equally with regard to their advancement and other aspects of their career. ${ }^{14}$ The judgment of a board is based on the need to secure the par condicio of all interested parties. This entails the absence of any bias in favour or against any of them. The rules concerning ordinary judges have to be followed as far as possible as a guarantee of objectivity and fairness..$^{15}$ The individual subject to the sanctioning power of the executive is entitled to an antecedent defense. ${ }^{16}$

${ }^{8}$ Comune di Bologna c. Prefetto di Bologna (5th Sec., Apr. 28, 1956, No. 314), C.S. 1956, 475,476 .

'Boezio c. Prefetto di Salerno (4th Sec., Oct. 16, 1956, No. 944), C.S. 1956, 1138.

${ }^{10}$ Ditta Autolinee Guido Reni c. Ministero trasporti (4th Sec., Oct. 23, 1957, No. 961), C.S. 1957,1248 .

${ }_{11}$ Marziale c. Ministero pubblica istruzione (6th Sec., Oct. 22, 1958, No. 784), C.S. 1958, $1171,1174$.

12 Ditta Fratelli Petrucci c. Comune di Ascoli Piceno (4th Sec., Oct. 30, 1957, No. 984), C.S. 1957, 1257, 1263.

${ }^{13}$ Bottari c. Amministrazione provinciale di Sassari (5th Sec., Sept. 27, 1957, No. 722), C.S. 1958,989 .

14 Comune di Bologna c. Prosperi (6th Sec., Mar. 8, 1958, No. 73), C.S. 1958, 275, 277.

${ }^{15}$ Tirelli c. Ministero pubblica istruzione (6th Sec., Oct. 31, 1956, No. 834), C.S. 1956, $1280,1283$.

16 Prociani c. Ministero agricoltura e foreste (4th Sec., Oct. 23, 1957, No. 698), C.S. 1957, $1303,1305$. 
There is a misuse of power if the grounds stated demonstrate injustice ${ }^{17}$ or perplexity, are generic, refer to divergent advice, ${ }^{18}$ or are different from the real grounds which are not expressed. ${ }^{19}$ The same is true if an internal rule, by which an agency binds itself, is breached without justification. ${ }^{20}$

It should be added that only written evidence may be submitted to the Council. But the proceeding is inquisitorial. The board has power to make further inquiries and request an agency to produce documents in its hands. Failure to comply is presumed to amount to an admission of guilt. When the Council has power to pass on the discretion of an act, as we shall shortly see, any means of evidence is permitted. Oral examination, however, is not carried at the hearing, where only written reports are submitted. Legal arguments are briefly stressed at the hearing by counsel of the appellant, the executive, and other parties. All decisions are published.

Special jurisdiction of the Council of State.-The two special jurisdictions of the Council of State deal with matters expressly reserved by the law. Under the first is the power of the Council to go into the "opportunity" of an act, that is, the use of discretion. There is jurisdiction to review illegality as well; this is simply an extension of the general jurisdiction already described. The Council here is entitled to check the expediency, utility, or justice of an act, according to flexible standards of good administration, or with a view to securing a fair treatment of individual interests. If the appeal is upheld the Council will quash, revise, or replace the administrative act. In other words, it will exercise an administrative power with a judicial process and in a judicial manner, substituting its own judgment for that of the administrative authority. Administrative discretion thus acquires legal relevance. Not only legitimate interests come to the fore, but "simple" interests-which are not otherwise protected-are also given a prominent position. The Council has jurisdiction not only over minor disputes relating mainly to local government and public works, but over appeals to obtain the fulfillment of the administration's duty to comply with the decision of an ordinary court. The court's recognition that an individual's right has been infringed thus finds its sanction.

The "exclusive" jurisdiction of the Council of State excludes that of ordinary courts, in view of the close connection between legal rights and legitimate interests which is noticeable in some matters. The single jurisdiction over these matters avoids the serious consequences which would otherwise arise from a mistaken appeal to the wrong judge. An administrative act can then be judicially quashed, even if it infringes a legal right. A right may automatically spring up when an act is set aside. Thus, when the illegal dismissal of a public

${ }^{17}$ Castagnini c. Comune di Tregnago (5th Sec., Feb. 23, 1957, No. 80), C.S. 1957, 204, 205.

${ }^{18}$ Carbonin c. Ministero lavori pubblici (4th Sec., Mar. 8, 1957, No. 292), C.S. 1957, 317,319 .

${ }^{19}$ Comune di Livorno c. Ministero interni (5th Sec., Apr. 6, 1957, No. 185), C.S. 1957, 479,483 .

${ }^{20}$ Morone c. Prefetto di Cremona (4th Sec., Oct. 21, 1958, No. 682), C.S. 1958, 1049. 
officer is annulled with retroactive effect, this will create a title in him to obtain the back salary which he missed. But when a question concerning a right is a consequence of the Council's decision but deals with a different issue, such as the award of damages as a result of the annullment of an act held to be illegal, the case must be referred to the ordinary courts. The "exclusive" jurisdiction also contains disputes concerning payment of salaries or allowances due from an agency to its officers. There may be an administrative act, such as the refusal to pay, but this may not be the case. In such exceptional cases, then, no act will be challenged. The short period of limitation allowed for the appeal to the Council will be replaced here by the longer one available for the protection of rights before ordinary courts.

The main subject of "exclusive" jurisdiction is public employment, as the preceding examples have shown. All employment relationships with a government agency or a public body are considered to be of a public nature, although there are a few exceptions to this rule. It may be said without fear of exaggeration that public officer's litigation constitutes the majority of the Council's work. It was provided by statute in 1924 that if a public body had not established special regulations for its personnel, the rules governing private employment would apply. For some years the number of public business corporations has been growing. And since many of those corporations exercise the same commercial, industrial, or banking powers as private enterprises, the Code of Civil Procedure of 1942 provided that disputes of their employees should be submitted to ordinary courts. The same substantive discipline called for the same procedural settlement. The survival of this provision and its interpretation in connection with the 1947 Constitution were subjects hotly debated in the immediate aftermath of the war when dismissal of excess personnel and the termination of useless agencies provided the incentive to litigate many cases. After expressing several tentative positions, the Council held in 1949 that the clause had been completely repealed and did not budge from this decision. ${ }^{21}$ Since the preceding legislation had been implicitly revived and disputes concerning the staff of public enterprises were of a public nature, they belonged to the jurisdiction of the Council. But the Court of Cassation, acting as a judge of "conflicts of jurisdiction," has constantly denied this doctrine and quashed decisions of the Council applying it; the Court of Cassation bases its action on a "lack of jurisdiction" in the Council. Jurisdiction belongs to ordinary and not to administrative courts. ${ }^{22}$ The Supreme Court, however, has narrowed somewhat the breadth of its disagreement with the highest administrative court, discriminating among public enterprises. At the same time, the opinion is gaining ground that the relationships of agencies with their personnel, ruled as those relationships are by private law, are of a private nature too and thus reviewable only by ordinary courts.

${ }^{21}$ Rocco c. Consorzio canapa (6th Sec., Apr. 30, 1957, No. 188), C.S. 1957, 504.

22 Azienda elettrica Bolzano c. Minestrina (Joint Sec., May 7, 1958, No. 1507), 84 F.I. 1959, I, 205. 